\title{
Renewable Energy Production, Energy Consumption and Sustainable Economic Growth in Turkey: A VECM Approach
}

\author{
Dilek Temiz Dinç ${ }^{1}$ and Ece C. Akdoğan ${ }^{2, *}$ \\ 1 Department of International Trade, Çankaya University, Ankara 06790, Turkey; dilektemiz@cankaya.edu.tr \\ 2 Department of Banking and Finance, Çankaya University, Ankara 06790, Turkey \\ * Correspondence: ece@cankaya.edu.tr
}

Received: 29 January 2019; Accepted: 24 February 2019; Published: 28 February 2019

check for updates

\begin{abstract}
There exists a highly interrelated relationship between energy, the environment and growth where the efficient management of this nexus is not only a must for sustainable development and human wellbeing but is also a basis for formulating sound economic policies harnessed with energy and environmental policies. Thus, this paper aims at investigating the causal relationships among renewable energy production, total energy consumption and economic growth for Turkey both in the long and short runs. The analyses are conducted by using the Johansen-Juselius co-integration test, the vector error correction model, Granger causality, impulse-response functions and variance decomposition for the period 1980-2016. Our findings obtained for the causal relationship between renewable energy and economic growth points to a bidirectional relationship both in the short and in long runs that promote feedback hypothesis, and it also reports a causal relationship running from energy consumption to economic growth both in the short and long runs, supporting the growth hypothesis. However, no consistent result could be obtained for the short run relationship from economic growth to energy consumption. These results indicate that increased renewable energy production and decreased energy consumption are vital for Turkey's sustainable development.
\end{abstract}

Keywords: sustainable economic growth; energy consumption; renewable energy

\section{Introduction}

Energy, the environment and sustainable development are highly interconnected. Given the problems associated with the supply and the use of energy relating to environmental concerns such as global warming, air pollution, the emission of radioactive substances, ozone depletion and forest destruction on one hand, and the pressures on environmental quality exerted by economic growth through the consumption of energy as a transmission channel on the other, it is clear that a society cannot attain sustainable development without utilizing environment friendly energy sources. Besides, as higher efficiency processes lead to less resource utilization and pollution, there exists a strong relationship between energy efficiency and environmental impact. Additionally, since all energy resources impose, more or less, some environmental impact, the limitations imposed by environmental emissions on sustainable development and the corresponding negative impacts can be at least partially overcome through improvements in energy efficiency. Moreover, diversifying the energy matrix, particularly in favor of renewables, and improving the energy efficiency will not only help reduce the environmental impacts and the associated health costs of economic activity but they will also enable a country to reduce the import bills and to hedge the price volatility in energy markets which, in turn, will support sustainable growth in the long run. Thus, there exists a highly interrelated relationship among energy, the environment and growth, where the efficient management of this nexus is not only a must for sustainable development and human wellbeing but a precondition of 'being in the future'. 
The vitality of the related challenges, opportunities, threats and consequences have raised intense interest from a wide international community recently, including the academia which has resulted in a vast array of past empirical research addressing the energy-environment-growth nexus with mixed results. Past empirical studies focusing on the causal relations among energy, economic growth and environment can be grouped under three streams of research based on the causality direction: (i) between the energy consumption and economic growth, (ii) between the environment and economic growth and (iii) among all variables at the same time [1].

The first one, through discussing that an excessive economic performance necessitates vast energy consumption where efficient energy use requires a high economic growth, concentrates on the causality between economic growth and energy use. This causal relationship between energy use and economic growth has been widely debated in the literature, which is structured around four hypotheses, namely, the Growth, Conservation, Feedback and Neutrality Hypotheses. The Growth Hypothesis proposes that energy consumption plays an explicitly important role in economic growth, providing support for the one-way causality relationship from energy consumption to income, and thus energy conservation policies targeted at decreasing the energy consumption will have a negative impact on growth. In contrast, the Conservation Hypothesis proposes a one-way causality from growth to energy consumption, attributing a vital role in energy consumption in the economic development process. Therefore, in such a case, energy supply shocks may have a light impact or no adverse effect on growth. The Feedback Hypothesis calls for a bidirectional relationship between production and energy consumption where energy conservation policies targeted at reducing the energy use may deteriorate growth while changes in economic growth will reflect back in energy consumption. Lastly, the Neutrality Hypothesis asserts that no causal relationship exists between economic growth and energy consumption and thus the energy conservation policies targeted at reducing the energy use will be of no effect on growth. Empirically, each and every above-explained hypothesis has found support. For instance, on a panel of six Middle East and North Africa (MENA) countries, Reference [2] reported a short-run Granger causality running from electricity consumption to GDP and Reference [3] found a unidirectional causality from biomass energy consumption to real output for the U.S. By focusing on China, Reference [4] suggested that a 1\% increase in renewable energy consumption increases the real GDP by $0.12 \%$ and by focusing on Malaysia, Reference [5] found that diesel and motor petrol are the major contributors to economic growth in the long-run while Reference [6] confirmed that energy consumption affects the economic growth positively in Vietnam. As all the above-mentioned studies reported a causal relationship running from energy consumption to growth, they provide support for the growth hypothesis. However, there are also studies that support the Conservative Hypothesis. For example, Reference [7] examined the causal relationship between the total production and energy consumption for 20 Organization for Economic Co-operation and Development (OECD) countries by using the Granger causality test, and suggested a unidirectional Granger causality from output to energy use, providing support for the Conservation Hypothesis. Additionally, the findings of Reference [8] obtained through co-integration tests report a unidirectional causality from income to energy consumption for Brazil. With panel data for the period 1990-2013 for the 29 OECD countries, Reference [9] also reported that both the non-renewable and renewable energy consumptions are positively associated with higher economic growth rates. Besides, there are still studies that provide support for the feedback and the Neutrality Hypotheses. For example, the results of Reference [10] for Indonesia and Reference [11] for 18 emerging market countries provide support for the Feedback Hypothesis by reporting on bidirectional causality, while the findings of Reference [12] for the USA and Reference [13] for 27 European countries promote the Neutrality Hypothesis as they do not provide any significant causality. There are also studies that specifically focus on Turkey, which provide mixed results as well. For instance, by using the Vector Error Correction Model, Reference [14] provided support for the Growth Hypothesis, while the study in Reference [15], carried out the Granger Causality, ARDL and Co-Integration Tests and suggested the Neutrality Hypothesis, whereas the findings of Reference [16] proposed the Feedback Hypothesis. Reference [17] 
found that energy consumption and economic growth are co-integrated in the long run by using the vector error correction model. Further, the results of Reference [18] obtained through the Bayer-Hanck co-integration test and the Toda-Yamamoto causality test report a long run positive relationship from renewable energy use to economic growth and the findings of Reference [19] obtained via the Autoregressive Distributed Lag Model (ARDL)-bound -bound and Toda-Yamamoto causality tests show that the variables are co-integrated and indicate a one-way causality that runs from renewable energy consumption to growth.

The second line of researches is based on the Environmental Kuznets Curve (EKC) Hypothesis which assumes an inverted U-shaped relationship between environmental quality and economic growth, implying that environmental degradation first increases with the output but then starts to fall upon reaching a threshold. An examination of the past empirical evidence again provides inconclusive results. While some support the EKC Hypothesis, such as Reference [20], others do not provide support, such as Reference [21]. Still, some others such as Reference [22] proposed an $\mathrm{N}$-shaped relationship. While the findings of Reference [23] obtained for Tunisia over the period of 1961-2004 demonstrated a monotonically rising relationship relative to the economic growth of $\mathrm{CO}_{2}$, the results of Reference [24] displayed an inverted U-shaped nexus among the environmental and economic growth for Malaysia, both in the long and short runs. Besides, through focusing on the validity of the EKC Hypothesis in the MENA Region for the period 1981-2005, Reference [25] reported a quadratic relationship between the environment proxy and growth for the region as a whole where the estimated long-run coefficients for the majority of the MENA countries, although supporting varying threshold levels, provide weak evidence on the validity of the EKC Hypothesis. Nevertheless, as also argued by Reference [1], the EKC literature signifies that the economic development process led by energy consumption may exert significant pressure on environmental quality. There exist a few studies focusing on Turkey in the literature with regard to this stream of research. For example, Reference [26], which tested the EKC Hypothesis by applying co-integration techniques for the time series with provincial data for the periods of 1968-2003 and 1992-2001, suggests a monotonic nexus, while the findings of Reference [15] suggested a positive link between $\mathrm{CO}_{2}$ emissions and trade.

Finally, the third line of researches which, in a sense, combines the approaches of the above-discussed streams, concentrates on the three-way linkages among energy consumption, the environment and economic growth where the past empirical evidence, again, provides conflicting results. For example, Reference [27] searched for these relationships by utilizing Vector Error Correction Model (VECM) and suggest that the $\mathrm{CO}_{2}$ emissions and renewable energy consumption are co-integrated while Reference [28] demonstrated bidirectional causalities between energy consumption and output as well as between output and environmental quality, and unidirectional causality from energy consumption to $\mathrm{CO}_{2}$ emissions. By using panel unit root tests, panel co-integration methods and panel causality tests to investigate the relationship between energy consumption (EC), GDP and $\mathrm{CO}_{2}$ emissions for the 15 MENA countries covering the annual period 1973-2008, Reference [29] revealed that there is no causal link between GDP and $\mathrm{EC}$, as well as between $\mathrm{CO}_{2}$ emissions and $\mathrm{EC}$ in the short run while unidirectional causality running from GDP and $\mathrm{CO}_{2}$ emissions to EC are detected for the long run. Based on Granger causality test results, Reference [30] reported bidirectional causality between oil consumption, $\mathrm{CO}_{2}$ emission and economic growth in short and long run for MENA countries during the period 1980-2009. Through panel co-integration and panel vector error correction modeling techniques based on the panel data for 28 provinces in China during 1995-2007, Reference [31] reported bidirectional causality between $\mathrm{CO}_{2}$ emissions and energy consumption, as well as between energy consumption and economic growth, and determined energy consumption and economic growth as the long run causes for $\mathrm{CO}_{2}$ emissions, and $\mathrm{CO}_{2}$ emissions and economic growth as the long run causes for energy consumption. For Turkey, in the study on energy-environment-growth nexus, Reference [32] reported a long-run linkage among all variables for the period 1960-2007. 
An excellent review of the literature on the energy-environment-growth nexus can be reached in Reference [1], which argued that understanding these dynamic linkages among energy variables, environmental quality and growth is the keystone for new insights on energy and environmental policy and forms the basis for making sound economic policies and being consistent with environmental goals and energy policy objectives. With the aim of providing another insight into these interconnected relations, this paper is designed to investigate the causal relationships among renewable energy production, total energy consumption and economic growth for Turkey both in the short and long runs. As the majority of the past empirical research focusing on Turkey investigated such relations in pairwise, examining the three-way linkages among variables constitutes a distinctive feature of this study. By the end of 2016, Turkey had a total established renewable energy production capacity of $35 \mathrm{GW}$, while the renewable sources accounted for 35\% of her total electricity production [33]. The evolution of Turkey's renewable energy production as a percentage of her total energy production for the period of 1980-2016 is depicted in Figure 1 and the composition of her renewable energy production for 2016 is provided in Figure 2.

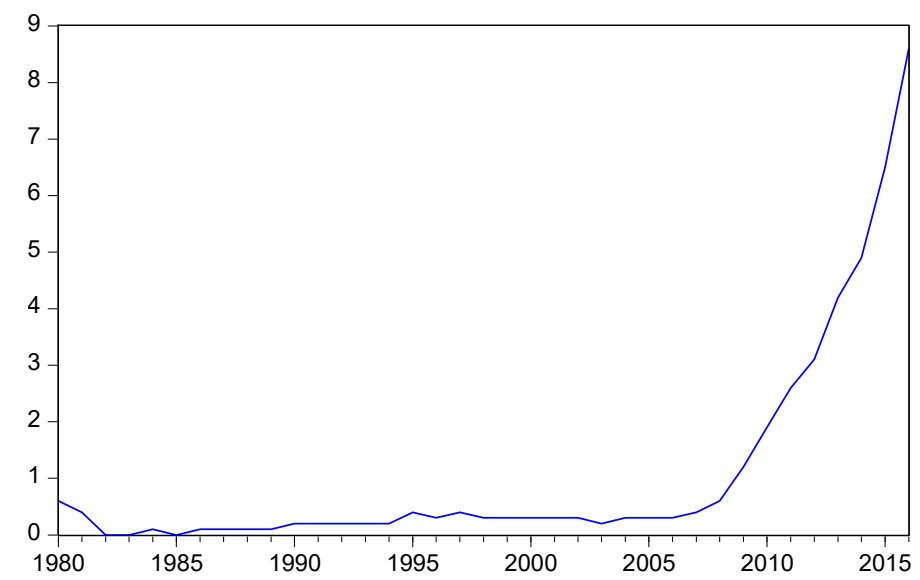

Figure 1. The share of renewable energy production (\%). Source: Turkish Statistical Institute (TUIK) [34].

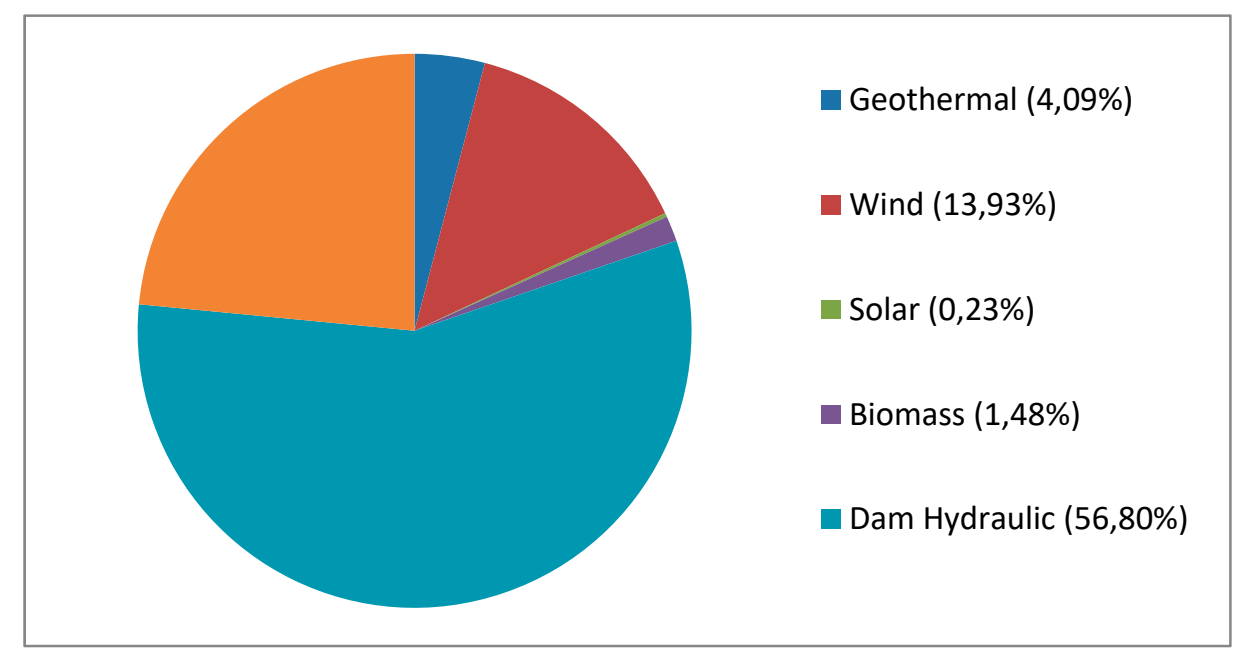

Figure 2. The composition of renewable energy production in Turkey in 2016. Source: Turkish Statistical Institute (TUIK) [34].

As can be followed from Figure 1, Turkey holds an inconsiderable share of renewable energy production under $1 \%$ before 2008. A rapid increase is observed after this, reaching $8.6 \%$ in 2016 . When the composition of Turkey's renewable energy production is examined as shown in Figure 2, it can be seen that $80 \%$ of Turkey's renewable energy production is supplied by hydraulic sources while 
Turkey's solar energy production has a negligible share of only $0.23 \%$. However, although Turkey holds a considerably high potential of hydraulic, geothermal, wind and solar energies compared to EU countries, her actual realization level is at considerably low levels. Besides, Turkey is a net energy importer and thus not only suffers from being a foreign energy dependent country but also from highly vulnerable price shocks in the global energy markets. Thus, the causal relationship among renewable energy production, energy consumption and economic growth is a very important policy concern for Turkey.

\section{Materials and Methods}

The aim of this study is to test the hypothesis, "there exists a relationship among renewable energy production, energy consumption and economic growth in Turkey". For this purpose, econometric analyses are conducted for the period 1980-2016 by using annual data. All the data used in the econometric analyses were obtained from the Turkish Statistical Institute and Ministry of Energy and Natural Resources, and the econometric analyses were performed by using the EViews 9 software.

The variable definitions used in the study are

RENEW: Renewable Energy Production (GWh)

ENC: Total Energy Consumption (GWh)

GRWTH: Chained volume index per capita GDP growth rate (\%)

The empirical model established in the study is

GRWTH = $\mathrm{f}($ RENEW, ENC)

Firstly, Augmented Dickey-Fuller (ADF) [35], Phillips-Perron (PP) [36], Kwiatkowski-Phillips-Schmidt-Shin (KPSS) [37] and Ng-Perron [38] unit root tests were applied to check whether the series were stationary or not. The reason why four tests were included at the same time was to support the results of the stagnation test. In order to determine the lag length during the unit root tests, the Schwarz Information Criterion (SC), Akaike Information Criterion (AIC) and Hannan-Quinn information criterion (HQ) were used.

The ADF and PP unit root test results for the variables used in this study are provided in Table 1, where the values in the parentheses indicate the lag length.

Table 1. The Augmented Dickey-Fuller (ADF) and Phillips-Perron (PP) unit root test results.

\begin{tabular}{|c|c|c|c|c|c|c|}
\hline \multirow{2}{*}{$\begin{array}{l}\text { Variable } \\
\text { RENEW }\end{array}$} & \multicolumn{2}{|c|}{ ADF Test Statistics } & \multicolumn{2}{|c|}{$\begin{array}{l}\text { Phillips-Perron Test } \\
\text { Statistics }\end{array}$} & \multirow{2}{*}{$\begin{array}{c}\text { Trend-Fixed } \\
\text { None }\end{array}$} & \multirow{2}{*}{$\begin{array}{c}\text { Result } \\
\text { not stationary }\end{array}$} \\
\hline & $3.156141(2)$ & $p=0.9993$ & $6.095761(5)$ & $p=0.9999$ & & \\
\hline ENC & $-0.703046(0)$ & $p=0.9652$ & $-0.421391(3)$ & $p=0.9828$ & trend-fixed & not stationary \\
\hline GRWTH & $-2.827951(0)$ & $p=0.1971$ & $-3.383561(6)$ & $p=0.0695$ & Fixed & not stationary \\
\hline DRENEW & $-3.400681(0)$ & $p=0.0013$ & $-3.508356(2)$ & $p=0.0009$ & None & Stationary \\
\hline DENC & $-5.665581(1)$ & $p=0.0003$ & $-3.823716(2)$ & $p=0.0062$ & trend-fixed & Stationary \\
\hline DGRWTH & $-5.779360(0)$ & $p=0.0002$ & $-5.199447(0)$ & $p=0.0001$ & Fixed & Stationary \\
\hline
\end{tabular}

Note: A $p$-value $>0.05$ indicates that the unit root is detected (not stationary); otherwise, it means that there is no unit root (stationary).

The " $\mathrm{D}$ " used in front of the variables indicates the first difference.

The results of the ADF and the PP unit root tests applied on the levels of the variables show that the variables were not stationary while their first degree differences were, indicating that the difference of the variables was stationary. Next, the KPSS trend stationary test was performed to provide support that the difference of the series was stationary. The KPSS test results are presented in Table 2.

According to Table 2, the LM test statistics for the levels of the variables were not stationary as they were absolutely greater than the KPSS test critical values at the $5 \%$ significance level, leading to the conclusion that they contained a unit root while the results obtained by applying the same test to the first order difference of the variables show that the difference of the variables was stationary. Thus, the results obtained from the KPSS test support the results obtained from the ADF and PP tests. 
Table 2. The Kwiatkowski-Phillips-Schmidt-Shin (KPSS) test results.

\begin{tabular}{ccccc}
\hline Variable & LM-Stat & Fixed-Trend & Asymptotic Critical Value (5\%) & Result \\
\hline RENEW & 0.180635 & Fixed-trend & 0.146000 & not stationary \\
ENC & 0.197468 & Fixed-trend & 0.146000 & not stationary \\
GRWTH & 0.291546 & Fixed-trend & 0.146000 & not stationary \\
DRENEW & 0.119120 & Fixed-trend & 0.146000 & Stationary \\
DENC & 0.048070 & Fixed-trend & 0.146000 & Stationary \\
DGRWTH & 0.171811 & Fixed & 0.463000 & Stationary \\
\hline
\end{tabular}

Additionally, the Ng-Perron [38] unit root test, which provides more consistent and effective results in case of a small number of observations, was also performed, and the results are summarized in Table 3.

Table 3. The Ng-Perron test results.

\begin{tabular}{ccccc|cccc}
\hline \multicolumn{4}{c}{ Constant } & \multicolumn{4}{c}{ Constant+Trend } \\
\hline Variable & $\mathbf{M Z}_{\mathbf{a}}$ & $\mathbf{M Z}_{\mathbf{t}}$ & $\mathbf{M S B}$ & $\mathbf{M P T}$ & $\mathbf{M Z}_{\mathbf{a}}$ & $\mathbf{M Z}_{\mathbf{t}}$ & $\mathbf{M S B}$ & $\mathbf{M P T}^{*}$ \\
\hline RENEW(1) & -2.17971 & -1.79321 & 0.82268 & 6.0697 & -5.00173 & -2.21705 & 0.44326 & 7.6446 \\
\hline ENC $(1)^{*}$ & -1.83669 & -1.23683 & 0.67340 & 4.3762 & -0.07634 & -0.03857 & 0.50530 & 6.19080 \\
\hline GRWTH(1) & -2.06326 & -0.99943 & 0.48439 & 4.7135 & -17.1071 & -2.65035 & 0.17852 & 5.75487 \\
\hline DRENEW(0) & -10.1068 & -3.39106 & 0.13552 & 2.8082 & -24.9272 & -3.52789 & 0.14153 & 3.67037 \\
\hline DENC(0) & -14.8960 & -2.55164 & 0.17130 & 2.2941 & -38.5859 & -4.37168 & 0.11330 & 2.47194 \\
\hline DGRWTH(1) $^{*}(0)^{* *}$ & -14.6744 & -2.69874 & 0.18391 & 1.7074 & -20.0086 & -3.16290 & 0.15808 & 4.55465 \\
\hline $\begin{array}{c}\text { Asymptotic critical } \\
\text { value 5\% }\end{array}$ & -8.10000 & -1.98000 & 0.23300 & 3.17000 & -17.3000 & -2.91000 & 0.16800 & 5.48000 \\
\hline
\end{tabular}

Note: ( ) indicates lag length, ${ }^{*}$ refers to the constant model, ${ }^{* *}$ refers to the constant + trend model.

The null hypotheses of the MSB and MPT tests, as with the KPSS test, indicate that the series is stationary, whereas the null hypotheses of $\mathrm{MZ}_{\mathrm{a}}$ and $\mathrm{MZ}_{\mathrm{t}}$ tests show that the unit root is in the series, as in the PP and ADF tests. The Ng-Perron test was analyzed by Spectral OLS-Detrented Autoregressive (AR) Model Optimal lag lengths were determined in accordance with the HQ and SC information criterion. For the constant model, the lag length was one at the level series. Additionally, the first difference of the series was one for the GRWTH variable and 0 for the others. For the constant and trend models, the lag length in the level series was one. The first difference of the series was 0 for all variables. In Table 3 , series $I(1)$ is the first aware station since the $M Z_{a}$ and $M Z_{t}$ values in the first difference of the series were greater than the table value and the MSB and MPT values were smaller than the table value.

As all the variables included in the model were observed to be stationary at the first degree, a co-integration analysis was performed together with a Vector Autoregressive (VAR) analysis. In the VAR analyses, the most important condition is the accurate estimation of the VAR lag length, as determined by the information criteria. Table 4 shows the determination of the VAR lag length.

Table 4. The determination of Vector Autoregressive (VAR) lag length.

\begin{tabular}{ccccc}
\hline Lag & $\begin{array}{c}\text { Final Prediction } \\
\text { Error (FPE) }\end{array}$ & $\begin{array}{c}\text { Akaike Information } \\
\text { Criterion (AIC) }\end{array}$ & $\begin{array}{c}\text { Schwarz Information } \\
\text { Criterion (SC) }\end{array}$ & $\begin{array}{c}\text { Hannan-Quinn } \\
\text { Information Criterion (HQ) }\end{array}$ \\
\hline 0 & $9.78 \times 10^{21}$ & 59.14780 & 59.28248 & 59.19373 \\
1 & $2.67 \times 10^{17 *}$ & $48.63805^{*}$ & $49.17676^{*}$ & $48.82176^{*}$ \\
2 & $3.73 \times 10^{17}$ & 48.95706 & 49.89981 & 49.27856 \\
3 & $3.91 \times 10^{17}$ & 48.96795 & 50.31474 & 49.42725 \\
\hline
\end{tabular}

Note: * indicates lag order selected by the criterion (each test at $5 \%$ level).

As seen from Table 3, the FPE, AIC, SC and HQ information criteria indicate a lag length of 1. First of all, the identification test for a one-year lag VAR model was performed. A white heteroscedasticity test for the variance problem, a Jarque-Bera normality test for the normal distribution of error terms, and a Lagrange Multiplier-LM test for autocorrelation were also performed. The obtained results 
show that there is no problem of variance in the models, that the error terms are normally distributed and that there is no problem of autocorrelation. Therefore, the identification test of a one-year lag VAR model indicates that the model is consistent.

\section{Results and Discussion}

In the study, the Johansen-Juselius (JJ) [39] test was used for the co-integration analysis and the results are given in Table 5.

Table 5. The Johansen-Juselius JJ Test Results.

\begin{tabular}{ccccc}
\hline $\begin{array}{c}\text { Hypothesized } \\
\text { No. of CE(s) }\end{array}$ & Eigenvalue & $\begin{array}{c}\text { Trace } \\
\text { Statistic }\end{array}$ & $\begin{array}{c}\mathbf{0 . 0 5} \\
\text { Critical Value }\end{array}$ & Prob. \\
\hline None * & 0.625643 & 56.64530 & 42.91525 & 0.0013 \\
At most 1 & 0.343861 & 22.25624 & 25.87211 & 0.1321 \\
At most 2 & 0.193063 & 7.507833 & 12.51798 & 0.2945 \\
\hline \multicolumn{5}{c}{ Trace test indicates 1 cointegrating equation at the 0.05 level } \\
\hline Hypothesized & Max-Eigen & $\mathbf{0 . 0 5}$ \\
No. of CE(s) & Eigenvalue & Statistic & Critical Value & Prob. \\
\hline None * & 0.625643 & 34.38906 & 25.82321 & 0.0029 \\
At most 1 & 0.343861 & 14.74841 & 19.38704 & 0.2076 \\
At most 2 & 0.193063 & 7.507833 & 12.51798 & 0.2945 \\
\hline \multicolumn{4}{c}{ Max-eigenvalue test indicates 1 cointegrating equation at the 0.05 level } \\
\hline \multicolumn{4}{c}{ Note: * denotes rejection of the hypothesis at the 0.05 level. } \\
\end{tabular}

According to the results provided in Table 5, the null hypothesis, which claims the absence of no co-integration, is rejected by the trace and maximum eigenvalue test statistics and one co-integration relationship is found in the model. In other words, it can be said that there exists a long-run relationship between renewable energy production (RENEW), total energy consumption (ENC) and economic growth (GRWTH) in Turkey. In order to see the directions of these long-run relationships, normalized equations according to GRWTH, RENEW and ENC are examined, respectively. Normalized equations are interpreted according to the $5 \%$ significance level.

The normalized equation according to GRWTH:

$$
\begin{aligned}
\text { GRWTH }= & 0.412893+1.60 \mathrm{E}-05 \text { RENEW }-5.21 \mathrm{E}-05 \text { ENC } \\
& (t \text {-value }=2.4102) \quad(t \text {-value }=2.1158)
\end{aligned}
$$

The normalized equation according to RENEW:

$$
\begin{gathered}
\text { RENEW }=25.80519+62.49851 \text { GRWTH }-3.253508 \text { ENC } \\
(t \text {-value }=5.7461) \quad(t \text {-value }=1.1864)
\end{gathered}
$$

The normalized equation according to ENC:

$$
\begin{gathered}
\text { ENC }=79.31499+19.20958 \text { GRWTH }-0.307361 \text { RENEW } \\
(t \text {-value }=1.7175) \quad(t \text {-value }=1.1507)
\end{gathered}
$$

According to Equation (1), the impact of renewable energy production on economic growth is positive in the long run and the impact of the total energy consumption on economic growth is negative, implying that economic growth will increase as renewable energy production increases and/or the total energy consumption decreases in the long run. According to Equation (2), the impact of economic growth on renewable energy production, in the long run, is positive while the impact of the total energy consumption on renewable energy production is not significant. Finally, according to Equation (3), 
the impacts of economic growth and renewable energy production on the total energy consumption, in the long run, are insignificant. When the normalized equations are considered together, it can be seen that there exists a positive bidirectional relationship between economic growth and renewable energy production in the long run, whereas a unidirectional negative relationship running from energy consumption to economic growth exists, while no significant relationship could be found between renewable energy production and total energy consumption during the period covered.

The long-run relationship among the variables enables the establishment of a vector error correction model (VECM) that obviously includes the error correction term obtained though co-integration regressions and thus, is aimed at finding the source of the causality.

The VECM equations established in the study are

$$
\begin{aligned}
& \mathrm{D}(\text { GRWTH }) \mathrm{t}=\begin{array}{l}
\mathrm{c} 1+\mathrm{a} 1 \mathrm{ECT} \mathrm{t}-1+\mathrm{b} 1 \mathrm{D}(\text { GRWTH }) \mathrm{t}-1+\mathrm{d} 1 \mathrm{D}(\text { RENEW }) \mathrm{t}-1 \\
+\mathrm{e} 1 \mathrm{D}(\text { ENC }) \mathrm{t}-1+\mathrm{ut}
\end{array} \\
& \mathrm{D}(\text { RENEW }) \mathrm{t}=\begin{array}{l}
\mathrm{c} 2+\mathrm{a} 2 \mathrm{ECT} \mathrm{t}-1+\mathrm{b} 2 \mathrm{D}(\text { GRWTH }) \mathrm{t}-1+\mathrm{d} 2 \mathrm{D}(\text { RENEW }) \mathrm{t}-1 \\
+\mathrm{e} 2 \mathrm{D}(\text { ENC }) \mathrm{t}-1+\mathrm{ut}
\end{array} \\
& \mathrm{D}(\text { ENC }) \mathrm{t}=\mathrm{c} 3 \begin{array}{l}
+\mathrm{a} 3 \mathrm{ECT} \mathrm{t}-1+\mathrm{b} 3 \mathrm{D}(\text { GRWTH }) \mathrm{t}-1+\mathrm{d} 3 \mathrm{D}(\text { RENEW }) \mathrm{t}-1 \\
+\mathrm{e} 3 \mathrm{D}(\text { ENC }) \mathrm{t}-1+\mathrm{ut}
\end{array}
\end{aligned}
$$

The test results of the VECM are provided in Table 6.

Table 6. The vector error correction model (VECM) test results.

\begin{tabular}{cccc}
\hline & D(GRWTH) & D(RENEW) & D(ENC) \\
\hline ECT (-1) & -0.744221 & -10091.33 & 310.5355 \\
& {$[-2.13224]$} & {$[-3.61808]$} & {$[1.09370]$} \\
\hline D (GRWTH (-1)) & -0.111517 & 2043.057 & -150.3668 \\
& {$[-0.56511]$} & {$[1.29560]$} & {$[-0.93669]$} \\
\hline D (RENEW-1)) & $-3.48 \times 10^{5}$ & 0.744540 & 0.036394 \\
& {$[-1.58498]$} & {$[4.24442]$} & {$[2.03804]$} \\
\hline D (ENC (-1)) & -0.000137 & 6.866434 & 0.024778 \\
& {$[-0.46512]$} & {$[1.81721]$} & {$[0.10341]$} \\
\hline C & 2.470723 & -7796.184 & 4112.240 \\
& {$[1.72569]$} & {$[-0.68142]$} & {$[3.53076]$} \\
\hline R-squared & 0.975319 & 0.935107 & 0.294854 \\
\hline Adj. R-squared & 0.905361 & 0.926455 & 0.200834 \\
\hline F-statistic & 60.794389 & 108.0750 & 3.136093 \\
\hline \multicolumn{4}{c}{ t-statistics are provided in square brackets } \\
\hline \multicolumn{4}{c}{}
\end{tabular}

ECT (-1), the long run co-integration-related error correction term, shows the size of the past imbalance. In practice, the error correction coefficient is expected to be negative and statistically significant. According to the test results of the VECM, the error correction coefficients are negative and statistically significant at the 5\% significance level for Equations (4) and (5). As the error correction coefficient of Equation (3) is positive, it is excluded from the analyses. According to Equation (4), there exists a long run causal relationship from renewable energy production and total energy consumption to economic growth. If the value of $R^{2}$ is close to $1\left(R^{2}=0.975319\right)$, it can be said that the interpretation is consistent. This result supports the result obtained from the JJ co-integration test. According to Equation (5), there is a causal relationship between economic growth and total energy consumption to renewable energy production in the long run. The $R^{2}$ value is 0.935107 , which is also close to 1 . Therefore, the comments made for this equation are consistent as well. The causality from economic growth to renewable energy production supports the results obtained from the normalized Equation (2). 
In the next stage, the short run relationships among the variables were investigated. For that purpose, the Granger Causality test was performed and the results are shown in Table 7. According to the FPE and HQ information criteria, the lag length for the Granger causality test was determined to be 1 .

Table 7. The Granger causality test results.

\begin{tabular}{ccc}
\hline Variables & F-Statistic/Prob * & Causality \\
\hline DGRWTH-DRENEW & $6.03549 / 0.0196$ & $\rightarrow$ \\
\hline DGRWTH-DRENEW & $7.45389 / 0.0102$ & $\leftarrow$ \\
\hline \multicolumn{3}{c}{ DGRWTH $\leftrightarrow$ DRENEW } \\
\hline DGRWTH-DENC & $0.17453 / 0.8407$ & none \\
\hline DGRWTH-DENC & $3.81030 / 0.0339$ & $\leftarrow$ \\
\hline \multicolumn{4}{c}{ DENC $\rightarrow$ DGRWTH } \\
\hline
\end{tabular}

Note: * According to the $5 \%$ significance level.

According to these results, there is a bidirectional causality relationship between economic growth and renewable energy production and there is a one-way causality relationship from the total energy consumption to economic growth in the short run. It was seen that these findings obtained for the short run overlap with the long run findings.

The impulse-response functions analyze the effect of a random 'shock' in a variable on other variables in the system. That is, the impulse-response functions reflect the effect of a standard error shock on one of the random error terms in the present and future values of the internal variables. The impulse-response analysis results are shown in Figure 3.

Response to Cholesky One S.D. Innovations \pm 1 S.E.

(a) Response of DGRWTH to DRENEW

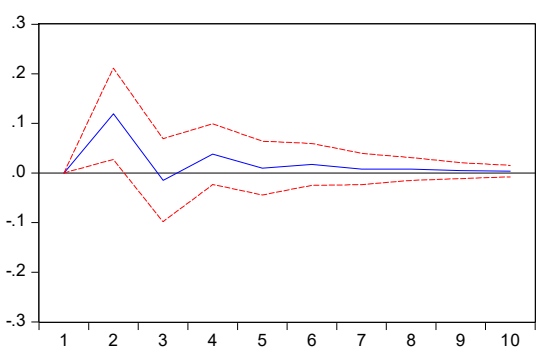

(c) Response of DGRWTH to DENC

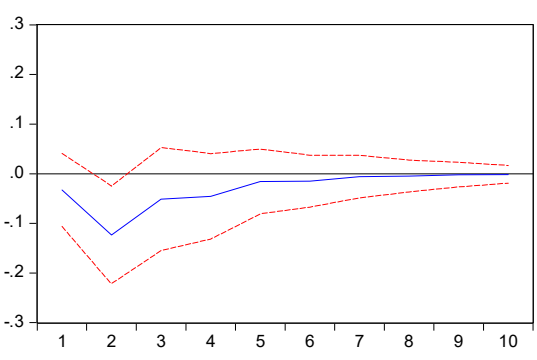

(b) Response of DRENEW to DGRWTH

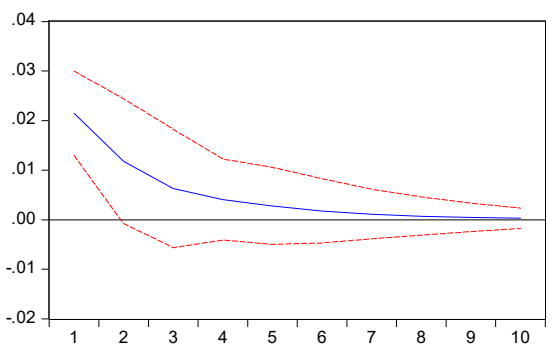

(d) Response of DENC to DGRWTH

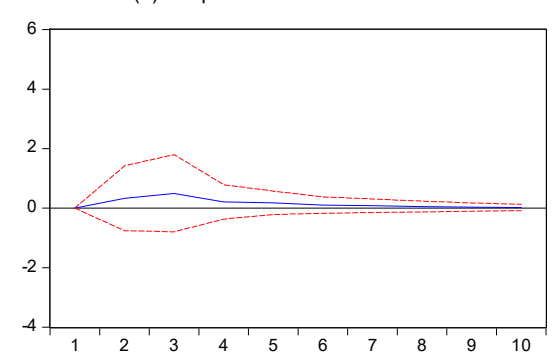

Figure 3. The Impulse-Response Functions. Note: the response of DGRWTH to DGRWTH, the response of DENC to DENC, the response of DRENEW to DRENEW, the response of DENC to DRENEW and the response of DRENEW to DENC are excluded from the analysis.

Figure 3a shows how the 1 standard error shock in renewable energy production affects economic growth. As can be seen from the graph, the effect follows a positive trend except for the third period. Figure $3 \mathrm{~b}$ depicts how the 1 standard error shock in the economic growth impacts renewable energy production. As can be seen from the graph, the effect is consistently positive and gradually decreasing. 
When Figure $3 \mathrm{a}$ and $3 \mathrm{~b}$ are evaluated together, a bidirectional positive causality relationship between economic growth and renewable energy production is observed. This result supports the Granger causality test results. Figure $3 \mathrm{c}$ shows how the 1 standard error shock in total energy consumption impacts economic growth. As can be seen from the graph, the effect is always negative and gradually decreasing. Figure $3 \mathrm{~d}$ shows how the 1 standard error shock in economic growth affects the total energy consumption. As can be seen from the graph, the effect is positive and follows a decreasing trend. When Figure $3 c$, d are considered together, a bidirectional causality relationship between economic growth and the total energy consumption is observed. However, the sign of the relationship is negative from the total energy consumption to growth and positive from economic growth to the total energy consumption. Nevertheless, the findings of the impulse-response analyses that report bidirectional causality can be concluded to provide partial support for the Granger causality test results that report unidirectional causality from energy consumption to economic growth.

One of the techniques used to determine the causes of the change in series is VAR decomposition. The variance decomposition obtained from the moving averages section of the VAR model refers to the sources of the shocks occurring in the variables themselves and in the other variables. Variance decomposition analysis not only decomposes the portions of a change in a variable originating from itself and from the other variables, but also gives information about the degree of causality relationships between the variables [40]. The results of the variance decomposition obtained from the one-lag-VAR model are estimated by the information obtained from the causality test, and the obtained results are provided in Table 8 .

Table 8. The variance decomposition test results.

\begin{tabular}{|c|c|c|c|c|}
\hline \multicolumn{5}{|c|}{ Variance Decomposition of DGRWTH: } \\
\hline Period & S.E. & DGRWTH & DRENEW & DENC \\
\hline 1 & 3.860196 & 100.0000 & 0.000000 & 0.000000 \\
\hline 2 & 4.403427 & 97.23220 & 0.367357 & 2.400444 \\
\hline 3 & 4.746272 & 85.48165 & 11.31464 & 3.203702 \\
\hline 4 & 4.905216 & 81.21662 & 11.72771 & 7.055669 \\
\hline 5 & 4.954741 & 79.62724 & 12.74888 & 7.623884 \\
\hline 6 & 4.964253 & 79.32636 & 12.98025 & 7.693386 \\
\hline 7 & 4.974161 & 79.07501 & 13.14306 & 7.781926 \\
\hline 8 & 4.984517 & 78.82486 & 13.22446 & 7.950685 \\
\hline 9 & 4.991229 & 78.66944 & 13.25006 & 8.080505 \\
\hline 10 & 4.994763 & 78.57734 & 13.24940 & 8.173257 \\
\hline \multicolumn{5}{|c|}{ Variance Decomposition of DRENEW: } \\
\hline Period & S.E. & DGRWTH & DRENEW & DENC \\
\hline 1 & 3175.635 & 10.70304 & 85.29366 & 4.00329 \\
\hline 2 & 4302.889 & 13.92654 & 80.69441 & 5.37905 \\
\hline 3 & 4833.457 & 15.93174 & 77.96612 & 6.10214 \\
\hline 4 & 4995.717 & 15.10012 & 78.89606 & 6.40382 \\
\hline 5 & 5063.246 & 15.06237 & 78.41348 & 6.74486 \\
\hline 6 & 5134.393 & 14.84166 & 78.21348 & 6.74486 \\
\hline 7 & 5190.959 & 14.68593 & 77.81326 & 7.50081 \\
\hline 8 & 5225.451 & 14.54314 & 77.30138 & 8.15549 \\
\hline 9 & 5245.711 & 14.30836 & 76.81576 & 8.57588 \\
\hline 10 & 5259.218 & 14.29055 & 76.63422 & 9.07524 \\
\hline \multicolumn{5}{|c|}{ Variance Decomposition of DENC: } \\
\hline Period & S.E. & DGRWTH & DRENEW & DENC \\
\hline 1 & 24574.54 & 0.000000 & 1.866623 & 98.13338 \\
\hline 2 & 34912.77 & 1.180887 & 1.616771 & 97.20234 \\
\hline 3 & 40171.47 & 1.325648 & 1.898489 & 96.77586 \\
\hline 4 & 41891.32 & 2.170199 & 1.789445 & 96.04036 \\
\hline 5 & 42685.96 & 3.431684 & 1.797846 & 94.77047 \\
\hline 6 & 43213.15 & 4.722443 & 1.993685 & 93.28387 \\
\hline 7 & 43554.18 & 5.718516 & 2.181807 & 92.09968 \\
\hline 8 & 43745.57 & 6.345798 & 2.317815 & 91.33639 \\
\hline 9 & 43853.81 & 6.698466 & 2.411226 & 90.89031 \\
\hline 10 & 43924.99 & 6.872166 & 2.474809 & 90.65303 \\
\hline
\end{tabular}

Note: Cholesky Ordering: DGRWTH DRENEW DENC. 
According to the results of variance decomposition, all of the changes realized in economic growth in the first period are explained by the variable itself. However, in the last period, almost $13 \%$ of the change in economic growth is explained by renewable energy production and almost $8 \%$ is explained by the total energy consumption. Considering the variance decomposition of renewable energy production, in the first period, $85 \%$ of the changes in renewable energy production is explained by the variable itself and about $11 \%$ of the changes is explained by economic growth. In the last period, approximately $77 \%$ of the change in renewable energy production is explained by the variable itself while almost $14 \%$ is explained by economic growth and $9 \%$ is explained by the total energy consumption. As the variance decomposition of the total energy consumption is considered, approximately $98 \%$ of the total energy consumption change in the first period is explained by the variable itself, roughly $2 \%$ by the renewable energy production, while no effect of economic growth could be signified. However, in the last period, nearly $7 \%$ of the total energy consumption change is found to be explained by economic growth. Overall, renewable energy production and total energy consumption are found to have an impact on economic growth while economic growth is found to affect the total energy consumption and renewable energy production. Therefore, these findings obtained from variance decomposition partially support the results of the Granger causality test for the short run. Besides, when the results of Granger causality, impulse-response and variance decomposition are evaluated together, a positive bidirectional causality relationship is obtained between economic growth and renewable energy production in the short run. Further, according to the Granger causality test between economic growth and total energy consumption, a one-way causality relationship from total energy consumption to economic growth is found while the results of the impulse-response analysis point to a negative causality. However, as the causality relationship between economic growth and energy consumption is considered, unlike the Granger causality test results, the results of impulse-response and variance decomposition reveal a causal relationship running from economic growth to total energy consumption where the direction of this relationship is determined to be positive by the impulse-response analysis.

\section{Conclusions}

This study searches for the causal relationships among renewable energy production, total energy consumption and economic growth by using econometric analyses with annual time series data by focusing on Turkey for the period 1980-2016. In order to determine the long-run relationships, a JJ co-integration test and VECM were applied and to determine the short run causality relationships, the Granger causality, impulse-response and variance decomposition analyses were conducted. The results of JJ co-integration and VECM tests led to the conclusion that there exists a long-run relationship between economic growth, renewable energy production and total energy consumption. According to normalized equations obtained from the co-integration test, there is a positive bi-directional causality relationship between economic growth and renewable energy production in the long run and a negative one-way causality running from the total energy consumption to economic growth.

According to the Granger causality test results, consistent with the findings obtained for the long run, there is a bidirectional causality relationship between economic growth and renewable energy production and a one-way causality relationship from total energy consumption to economic growth in the short run. Additionally, the variance decomposition test results demonstrate that renewable energy production and total energy consumption are found to have an impact on economic growth while economic growth was found to affect the total energy consumption and renewable energy production. Therefore, these findings obtained from variance decomposition partially support the results of the Granger causality test for the short run. Besides, when the results of the Granger causality, impulse-response and variance decomposition are evaluated together, a positive bidirectional causality relationship was obtained between economic growth and renewable energy production in the short run. Further, according to the Granger causality test between economic growth and total energy consumption, a one-way causality 
relationship from the total energy consumption to economic growth was found while the results of the impulse-response analysis point to a negative causality. However, as the causality relationship between economic growth and energy consumption is considered, unlike the Granger causality test results, the results of impulse-response and variance decomposition revealed a causal relationship running from economic growth to total energy consumption where the direction of this relationship was determined to be positive by the impulse-response analysis. Overall, our findings obtained for the causal relationship between renewable energy and economic growth both in the short and long runs supported the findings of References $[10,11,16,17]$, to name a few, and also promoted the feedback hypothesis. Besides, our findings also reported a causal relationship running from energy consumption to economic growth both in the short and long runs. Thus, in line with References $[2-6,14,19]$ and so forth, our results supported the growth hypothesis. However, no consistent result could be obtained for the short run relationship from economic growth to energy consumption.

The interdependency among renewable energy production, energy consumption and economic growth suggests that renewable energy is important for economic growth and likewise economic growth encourages the use of more renewable energy, while energy consumption adversely impacts economic growth, pinpointing the importance of improved energy efficiency and the use of renewable energy sources. Thus, governments should account for these interrelationships in formulating their energy policies and should promote renewable energy production, which may serve as the impetus for the modernization of the energy sector in meeting sustainability objectives specified by policymakers. In order to facilitate the expansion of the renewable energy sector, economic growth is vital in generating the required resources for the research and development of renewable energy technologies and building the necessary infrastructure.

Considering the extremely insufficient energy production capacity of Turkey, accompanied by the highly increasing energy demand, these results have important policy implications for Turkey. According to the 2018 Report [41] of the World Energy Council, Turkey, as of 2016, has a production of 17.9 million barrels of crude oil with a consumption of 27.6 million tons, while her natural gas production totals 381.6 million $\mathrm{m}^{3}$, with a consumption of 46.1 billion $\mathrm{m}^{3}$. Besides, for the 14-year period through 2002-2016, the consumption of crude oil and natural gas increased by $5.7 \%$ and $270 \%$, respectively, leading Turkey to rank second after China with respect to an increase in energy demand. With such an energy production/consumption outlook, Turkey carries a $72 \%$ foreign dependency rate in energy, where this dependency constitutes $98 \%$ in natural gas, $92 \%$ in fuel and $50 \%$ in coal. Being a net energy importer, Turkey is a foreign energy dependent country. This adversely affects her current account deficit which, in turn, hampers sustainable economic growth. Hence, reducing the total energy consumption accompanied by increasing the domestic energy production, and especially increasing the renewable energy production, is a must to attain sustainable growth in Turkey. For that purpose, policymakers should introduce and implement effective incentive mechanisms for the development of renewable energy projects that will also encourage the private sector to participate and undertake such projects.

Author Contributions: Conceptualization, D.T.D. and E.C.A.; methodology, D.T.D. and E.C.A.; software, D.T.D.; validation, D.T.D. and E.C.A.; investigation, D.T.D. and E.C.A.; resources, D.T.D. and E.C.A.; data curation, D.T.D. and E.C.A.; writing—original draft preparation, D.T.D. and E.C.A.; writing—review and editing, E.C.A.

Funding: This research received no external funding.

Conflicts of Interest: The authors declare no conflict of interest.

\section{References}

1. Tiba, S.; Omri, A. Literature survey on the relationships between energy, environment and economic growth. Renew. Sustain. Energy Rev. 2017, 69, 1129-1146. [CrossRef]

2. Narayan, P.; Smyth, R. Multivariate Granger causality between electricity consumption, exports and GDP: Evidence from a panel of Middle Eastern countries. Energy Policy 2009, 37, 229-236. [CrossRef] 
3. Payne, J.E. Survey of the international evidence on the causal relationship between energy consumption and growth. J. Econ. Stud. 2010, 37, 53-95. [CrossRef]

4. Fang, Y. Economic welfare impacts from renewable energy consumption: The China experience. Renew. Sustain. Energy Rev. 2011, 15, 5120-5128. [CrossRef]

5. Lean, H.H.; Smyth, R. Disaggregated Energy Demand by Fuel Type and Economic Growth in Malaysia; Discussion Paper 2013, 43-13; Department of Economics, Monash University: Melbourne, Victoria, Australia, 2014.

6. Tang, C.F.; Tan, B.W.; Ozturk, I. Energy consumption and economic growth in Vietnam. Renew. Sustain. Energy Rev. 2016, 54, 1506-1514. [CrossRef]

7. Bozoklu, S.; Yilanci, V. Energy consumption and economic growth for selected OECD countries: further evidence from the Granger causality test in the frequency domain. Energy Policy 2013, 63, 877-881. [CrossRef]

8. Pao, H.T.; Fu, H.C. The causal relationship between energy resources and economic growth in Brazil. Energy Policy 2013, 61, 793-801. [CrossRef]

9. Gozgora, G.; Laub, C.K.M.; Luc, Z. Energy consumption and economic growth: New evidence from the OECD countries. Energy 2018, 153, 27-34. [CrossRef]

10. Shahbaz, M.; Hye, Q.M.A.; Tiwari, A.K.; Leitão, N.C. Economic growth, energy consumption, financial development, international trade and $\mathrm{CO}_{2}$ emissions in Indonesia. Renew. Sustain. Energy Rev. 2013, 25, 109-121. [CrossRef]

11. Sadorsky, P. Renewable energy consumption and income in emerging economies. Energy Policy 2009, 37, 4021-4028. [CrossRef]

12. Yıldırım, E.; Sarac, S.; Aslan, A. Energy consumption and economic growth in the USA: Evidence from renewable energy. Renew. Sustain. Energy Rev. 2012, 16, 6770-6774. [CrossRef]

13. Menegaki, A.N. Growth and renewable energy in Europe: A random effect model with evidence for neutrality hypothesis. Energy Econ. 2011, 33, 257-263. [CrossRef]

14. Soytas, U.; Sari, R. Energy consumption, income, and carbon emissions in the United States. Ecol. Econ. 2007, 62, 482-489. [CrossRef]

15. Halicioglu, F. An econometric study of $\mathrm{CO}_{2}$ emissions, energy consumption, income and foreign trade in Turkey. Energy Policy 2009, 37, 1156-1164. [CrossRef]

16. Kaplan, M.; Ozturk, I.; Kalyoncu, H. Energy consumption and economic growth in Turkey: Cointegration and causality analysis. Rom. J. Econ. Forecast. 2011, 2, 31-41.

17. Gövdere, B.; Can, M. Energy consumption and economic growth: A cointegration analysis in Turkey. Int. J. Econ. Adm. Sci. 2015, 1, 101-114.

18. Alper, F.Ö. Yenilenebilir enerji ve ekonomik büyüme arasındaki ilişki: 1990-2017 Türkiye örneği. Çankırı Karatekin Üniversitesi İ̈BF Dergisi 2018, 8, 223-242.

19. Durğun, B.; Durğun, F. The causality relationship between renewable energy consumption and economic growth: Evidence from Turkey. Int. Rev. Econ. Manag. 2018, 6, 1-27. [CrossRef]

20. Farhani, S.; Mrizak, S.; Chaibi, A.; Rault, C. The environmental Kuznets Curve and Sustainability: A panel data analysis. Energy Policy 2014. [CrossRef]

21. Lee, C.C.; Lee, J.D. Income and $\mathrm{CO}_{2}$ emissions: Evidence from panel unit root and cointegration tests. Energy Policy 2009, 37, 413-423. [CrossRef]

22. Onafowora, O.A.; Owoye, O. Bounds testing approach to analysis of the environment Kuznets curve hypothesis. Energy Econ. 2014, 44, 47-62. [CrossRef]

23. Fodha, M.; Zaghdoud, O. Economic growth and environmental degradation in Tunisia: An empirical analysis of the Environmental Kuznets Curve. Energy Policy 2010, 38, 1150-1156. [CrossRef]

24. Lau, L.S.; Choong, C.K.; Eng, Y.K. Investigation of the environmental Kuznets curve for carbon emissions in Malaysia: Do foreign direct investment and trade matter? Energy Policy 2014, 68, 490-497. [CrossRef]

25. Arouri, M.H.; Ben Youssef, A.; M'henni, H.; Rault, C. Energy consumption, economic growth and $\mathrm{CO}_{2}$ emissions in Middle East and North African countries. Energy Policy 2012, 45, 342-349. [CrossRef]

26. Akbostanci, E.; Turut-Asik, S.; Tunc, G.I. The relationship between income and environment in Turkey: Is there an environmental Kuznets curve? Energy Policy 2009, 37, 861-867. [CrossRef]

27. Apergis, N.; Payne, J.E. Renewable energy, output, $\mathrm{CO}_{2}$ emissions, and fossil fuel prices in Central America: Evidence from a nonlinear panel smooth transition vector error correction model. Energy Econ. 2014, 42, 226-232. [CrossRef] 
28. Omri, A. $\mathrm{CO}_{2}$ emissions, energy consumption and economic growth nexus in MENA countries: Evidence from simultaneous equations models. Energy Econ. 2013, 40, 657-664. [CrossRef]

29. Farhani, S.; Ben Rejeb, J. Energy consumption, economic growth and $\mathrm{CO}_{2}$ emissions: Evidence from panel data for MENA Region. Int. J. Energy Econ. Policy 2012, 2, 71-81.

30. Al-Mulali, U. Oil consumption, $\mathrm{CO}_{2}$ emission and economic growth in MENA Countries. Energy 2011, 36, 6165-6171. [CrossRef]

31. Wang, S.S.; Zhou, D.Q.; Zhou, P.; Wang, Q.W. $\mathrm{CO}_{2}$ emissions, energy consumption and economic growth in China: A Panel data analysis. Energy Policy 2011, 39, 4870-4875. [CrossRef]

32. Öztürk, I.; Acaravci, A. The long-run and causal analysis of energy, growth, openness and financial development on carbon emissions in Turkey. Energy Econ. 2013, 36, 262-267. [CrossRef]

33. Karagöl, E.T.; Kavaz, İ. Dünyada ve Türkiye'de yenilenebilir enerji. Siyaset, Ekonomi ve Toplum Araştırmaları. Analiz 2017, 197, 1-30.

34. TUIK, Turkish Statistical Institute, Energy Statistics. 2016. Available online: http://www.tuik.gov.tr/ UstMenu.do?metod=temelist (accessed on 2 September 2018).

35. Dickey, D.A.; Fuller, W.A. Likelihood ratio statistics for autoregressive time series with a unit root. Econometrica 1981, 49, 1057-1072. [CrossRef]

36. Phillips, P.C.B.; Perron, P. Testing for Unit Roots in Time Series Regression. Biometrika 1988, 75, 335-346. [CrossRef]

37. Kwatkowski, D.; Phillips, P.C.B.; Schmidt, P.; Shin, Y. Testing the null hypothesis of stationarity against the alternative of a unit root. J. Econom. 1992, 54, 159-178. [CrossRef]

38. Ng, S.; Perron, P. Lag length selection and the construction of unit root tests with good size and power. Econometrica 2001, 69, 1519-1554. [CrossRef]

39. Johansen, S.; Juselius, K. Maximum likelihood estimation and inference on cointegration with application to the demand for money. Oxf. Bull. Econ. Stat. 1990, 52, 169-210. [CrossRef]

40. Enders, W. Applied Econometric Time Series; John Wiley and Sons Inc.: Hoboken, NJ, USA, 1995.

41. World Energy Council, Energy Outlook Report. 2018. Available online: http:/ /www.worldenergy.org.tr/ world-energy-outlook-2018/ (accessed on 15 February 2019).

(c) 2019 by the authors. Licensee MDPI, Basel, Switzerland. This article is an open access article distributed under the terms and conditions of the Creative Commons Attribution (CC BY) license (http:/ / creativecommons.org/licenses/by/4.0/). 